\title{
Impact of Service Quality On Trust and Loyalty: An Empirical Study On Private Hospitals in Kurdistan Region of Iraq
}

\author{
Osman Sahin ${ }^{1}$ \\ ${ }^{1}$ Department of Business Management, Faculty of Administrative Sciences, Tishk \\ International University, Erbil, Iraq \\ Correspondence: Osman Sahin, Tishk International University, Erbil, Iraq \\ Email: osman.sahin@tiu.edu.iq
}

Doi: $10.23918 /$ ejmss.v1i2p72

\begin{abstract}
Aim of this study was to investigate the impact of functional and technical service quality on the trust and loyalty of patients at private hospitals. The study conducted in Kurdistan region of Iraq. We have collected data via survey questionnaire from 322 patients or acquaintances of patients. He results revealed that functional and technical service quality at private hospitals had more or less equal impact on the trust of patients to that hospital. Besides, none of those service qualities significantly impacted the loyalty of patients. As trust had strongly significant and positive impact on the loyalty to that hospital, it was found that trust had a strong mediating role between service quality and loyalty to private hospital. There are managerial implications in the conclusion part.
\end{abstract}

Keywords: Functional Quality, Technical Quality, Hospital Service Quality, Trust, Loyalty, Private Hospital

\section{Introduction}

Around the world one of the largest and fastest growing industries is healthcare industry. Health services, which consume more than 10 percent of the gross domestic product (GDP) of most developed countries, can be a large part of the country's economy (Martin. et al, 2012; Ozmen Demir, and Celepli, 2013). In today's world, the health sector is one of the fastest-growing sectors based on getting more expectations of customers. Accordingly, the increase in the number of private hospitals around the world and their competition in this competitive market are incredible. Private hospitals have started a competitive war among themselves to increase their market share and get competitive advantages. What differentiates private hospitals in this situation from their competitors is their service 
quality. Today, consumers are more aware of alternative offers and improving service standards increased their expectations. They are also increasingly sensitive to the quality of the service they live in (Rahman \& Kutubi, 2013).

American Marketing Association defines service quality as an area of study that has developed to define and describe how services can be delivered in such a manner as to satisfy the recipient (Fisk, Grove \& John, 2012). According to Choudhuri (2016) service quality or quality of service is provided by the one and evaluated by the buyer on the basis of perceiving the quality of the services provided by the service provider and differentiating their expectations. Essay (2015) stated that the key to ensuring good service quality is to meet or exceed what customers expect from service. The quality of service perceived by customers can be defined as the scope of the inconsistency between the customer's expectations or desires and perceptions.

Service quality was classified by Gronross (1984) into two categories that are technical quality and functional quality (Demir, 2019a). Technical quality primarily focused on what consumers actually get from service and functional quality focused on the process of service delivery (Melisidou \& Theocharis, 2007). Customer perceived service quality is the priority for service providers to satisfy customers whose perception is based on technical quality perspective and functional quality perspective (Demir and Guven, 2017; Mohammed et al., 2020).

Today, the importance of technical quality and functional quality is gradually increasing in health services where competition is at a very high level. However, the increasing importance of functional quality in healthcare services is that customers are unable to evaluate technical quality. Zeithaml, et al, (1990) identified five service dimensions that are tangibles, reliability, responsiveness, assurance and empathy applied by service organizations. The fact that the service provided in healthcare service organizations is directly related to human life is proof of how important these dimensions of service are. Upadhyai, et al (2019) investigated what includes health care quality, the underlying dimensions of health care quality and how it is measured. The research states that there is no single set of standards of measurement available to assess healthcare quality.

Accordingly, Kurdistan is an emerging and developing market in the region (Demir and Budur, 2019). In spite of economic and political instability the region continues to develop in recent years and attracts entrepreneur for the future orientations (Budur and Demir, 
2019a, b; Top et al., 2020; Zaim et al., 2020). In this concept, especially private sectors are developing their selves as internal (leadership and employee development) and as external (customer orientation) qualities to reach competitive advantage in the region (Budur, 2018b). As in many regions of the world, the health sector is very dynamic in Kurdistan Region of Iraq, investors from around the world developed or developing countries where this sector is very successful are investing in the health sector here. For this reason, competition in the health sector in Kurdistan Region of Iraq is gradually increasing, which leads to an increase in the quality of service (Demir, Ozmen, and Rashid, 2014; Yildiz and Amin, 2020; Budur and Poturak, 2020). The private hospitals, which are opened, have to differentiate themselves in order to attract customers and satisfy them. Therefore, private hospitals should take into consideration the importance of service quality to get competitive advantages in this market. There are 40 private hospitals and 59 public hospitals in Kurdistan Region. Moore.et al., (2014) explores the health care system in the Iraqi Kurdistan Region by focusing on primary care and discusses what strategies can be followed to move towards a more effective and quality healthcare system.

Technical quality and functional quality are the dimensions of service quality in the health care system that hasn't been studied yet in the Kurdistan Region by researchers.

This research could be a road map for the successful implementation of the health care system for the Kurdistan Region of Iraq and for more efficient private hospitals that could provide more satisfaction, loyalty and then trust. It will also help the hospitals and the KRG government to reduce the migration of patients who move for a better service quality that can contribute to social and economic development and Kurdistan could be the center of health tourism in this region.

\section{Literature Review}

\subsection{Service Quality}

There is an increasing understanding of healthcare institutions that they need to improve their quality of service to keep patients from defecting to other doctors. The outcome of the study showed that there are relationships between patient commitment and patient loyalty and also patient trust and patient commitment to a doctor. Moreover, patient satisfaction affects the trust in the doctor and the doctor's reputation affects patient satisfaction and trust (Suki, 2011). 
Fatima, Malik \& Shabbir, (2018) analyzed hospital, patient satisfaction and loyalty accordingly based on the service quality of the hospital. The result of the study showed that better healthcare service tends to create more satisfaction and loyalty among patients. Healthcare service quality aspects (i.e. physical environment, customer-friendly environment, responsiveness, communication, privacy, and security) are positively associated with patient loyalty mediating patient satisfaction (Fatima, Malik \& Shabbir, 2018; Khan and Yildiz, 2020). Lertwannawit \& Gulid. (2011) evaluated the relationship between service quality, value, satisfaction and brand trust in medical tourists' behavioral loyalty.

Moliner (2009) stated that the perceived functional value has a significant effect on consumer satisfaction and trust. The main premises of loyalty are trust and satisfaction. There is a positive meaningful relationship between customer satisfaction and customer trust, which proves that customer satisfaction, is a pioneer of trust (Budur et al. 2018; Moliner, 2009). Kesuma et al (2013) argue that service quality affects customer loyalty positively and significantly. Implementing mediated Customer Relationship Management service quality affects customer loyalty. When customers feel that their expectations met, they would be satisfied and loyal (Demir and Mukhlis, 2017; Budur, 2018). To get more information about your costumers in order to fulfill their needs, CRM offers effective and efficient tools that make easier to meet customer needs understand them and make them loyal. Hospitals are medical service businesses based on the principle of trust; so service quality, patient satisfaction, and patient loyalty determine their success (Kesuma et al, 2013). Patients' experiences of the services of private hospitals have a strong influence on outcome variables, such as the willingness to return to the same hospital and reuse their services or recommend it to others (Arab et al, 2012).

The relationship between service quality and patient loyalty proves the importance of improving service quality and expanding market share to attract and retain patients. Meesala \& Paul (2018) did research on tangibility, reliability, responsiveness, assurance, and empathy (Service Quality dimensions), patient satisfaction and loyalty to the hospital (private hospital). They stated that reliability and responsiveness (not empathy, tangibility, and assurance) affect patient satisfaction. Patient satisfaction is directly related to the loyalty of patients to the hospital. Dachyar \& Minar (2018) did the research to improve outpatient loyalty in using National Health Insurance in a public hospital to be able to retain patients and acquire new potential patients. They found that satisfaction and trust are two 
strong factors that influence patient loyalty. Shabbir \& Malik (2016) examined the relative importance of healthcare quality dimensions such as physician care, nurses' care, supportive staff, operational activities, and physical care in terms of patient satisfaction and loyalty of patients in both public and private sector hospitals. The research showed that healthcare service quality is positively related to patient loyalty and patient satisfaction, and patient satisfaction mediates the relationship between healthcare service quality and patient loyalty.

The research results showed that quality of service has a positive relationship with value, satisfaction and brand trust, which have a direct impact on the behavioral loyalty of medical tourists. Moreover, value, satisfaction and brand trust have a mediation effect on the relationship between service quality and behavioral loyalty (Lertwannawit \& Gulid, 2011; Yildiz and Budur, 2019). Lestariningsih, Hadiyati \& Astuti (2018) did a research to test and prove the relationship of service quality, patient satisfaction, trust, and loyalty directly and through mediation in a public hospital. The research results showed that service quality is not significant to loyalty, but there are moderating variables that is trust. Trust strengthens the influence of service quality on loyalty. Today, public hospitals recognize the importance of service quality, which can affect patients' satisfaction, trust, and loyalty (Lestariningsih, Hadiyati \& Astuti, 2018)

Based on the review of literature, developed hypotheses suggest that;

H1 Functional service quality has direct positive impact on the trust to hospital

H2 Technical service quality has direct positive impact on the trust to hospital

H3 Functional service quality has direct positive impact on the loyalty to hospital

H4 Technical service quality has direct positive impact on the loyalty to hospital

\subsection{Trust}

Ehsan (2017) stated that how hospital managers could increase the level of patients' satisfaction and loyalty through high-quality services provided by quality management enablers. The researcher agrees that patients' satisfaction and loyalty could increase as a result of high-quality medical and treatment services in hospitals. Sumaedi (2015) explored the simultaneous effect of subjective norm, perceived behavioral control and trust on 
patient loyalty. The research outcomes revealed that subjective norm and trust positively affect patient loyalty. However, this study also found that perceived behavioral control does not significantly affect patient loyalty. Alrubaiee \& Alkaa'ida (2011) stated while the patient's perception of healthcare quality has a strong and positive effect on patient satisfaction and patient trust, patient satisfaction also significantly affects patient confidence. The research also shows that private hospital patients are more satisfied than public hospitals and have more trust in healthcare providers. Therefore, hypothesized model in this study suggest that.

H5 Trust directly and positively effects loyalty to hospital

\subsection{Loyalty}

Loyalty can be considered as a consequent feeling of customers about satisfaction (Torlak, Demir, and Budur, 2019). From this point, loyalty can be defined as continues and repeatedly satisfaction of a customer about a service or product from the behavior, shape, worth-of-mouth, etc. and repurchasing of concerning service or product (Oliver, 1999; Aydinli and Demir, 2015; Budur et al. 2019). When a customer feels loyal to a company, may will to pay more for this quality good or service rather than others companies (Demir, 2019).

Customer loyalty is an art for marketers, suppliers, and sellers since they need consumers and users for their products and services (Demir, 2019b). In this globally competitive market, patient loyalty is the priority of business success for healthcare providers as well as patient health outcomes because to satisfy and retain patients is getting more difficult day by day. $\mathrm{Wu}$ (2011) examined the effects of brand image of hospitals on customer satisfaction, loyalty and service quality (Demir and Mukhlis, 2017). The research found that positive brand image of hospitals that has positive effects on patient loyalty and satisfaction improves service quality. When a company offers service value, the company will get a high level of customer satisfaction and have good relationships with its customers who will be kept much easier. So, they won't defect to the competitors and they will be loyal as well. Suki (2011) explored the relationship between patient satisfaction, patient trust, patient commitment, patient loyalty, and doctors' reputation with doctor services. 


\section{EJMSS Eurasian Journal of Management \& Social Sciences}

\section{Methodology}

\subsection{Model of the study}

Based on the Aforementioned literature, we developed framework of the study as;

H1 Functional service quality has direct positive impact on the trust to hospital

H2 Technical service quality has direct positive impact on the trust to hospital

H3 Functional service quality has direct positive impact on the loyalty to hospital

H4 Technical service quality has direct positive impact on the loyalty to hospital

H5 Trust directly and positively effects loyalty to hospital

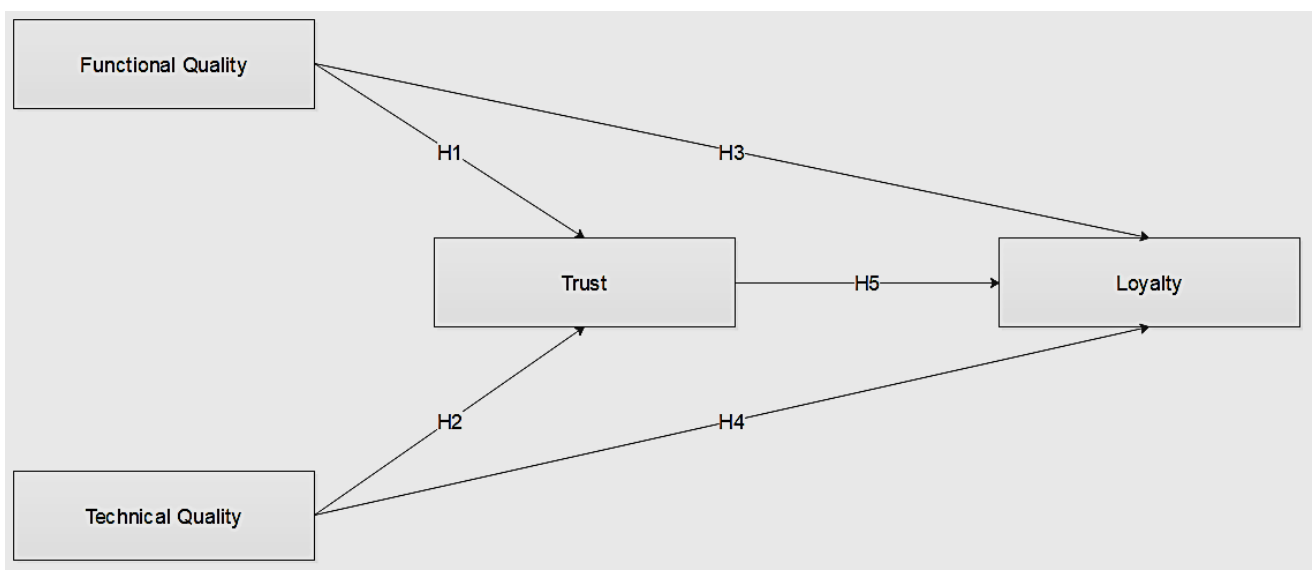

Figure 1: Model of the study

\subsection{Sample}

Sampling was collected from the various private hospitals all around Kurdistan Region of Iraq. Respondents were selected randomly among the patients, relatives of patients, and friends of patients. They have answered questions based on their experiences during their, their friends', and their relatives' medication experiences. Sample was collected via face 


\section{EJMSS}

Eurasian Journal of Management \& Social Sciences

to face interviews with the respondents. In total, we have collected data from 322 respondents.

\subsection{Measurement variables}

There were four main latent variables to test the framework of the study. In the beginning of the questionnaire, we have assured the participants that their private data wouldn't be declared anywhere in the study or somewhere else. Secondly, we have asked demographic questions which identified the gender, age, nationality, and whether the respondent was patient, relative of patient, of friend of a patient. After the demographic information, we have asked their experience in the hospitals from the technical quality, functional quality trust, and loyalty.

Technical quality contained five questions those were adopted from the study of Park et al., (2013) and functional quality was containing eight questions those were adopted from the study of Kang (2006). Secondly, trust questions contained five questions which were adopted from the study of Thaichon et al., (2014). Lastly, loyalty construct contained four questions those were adopted from the study of Chiou (2004). All questions from each latent variable was modified after being adopted to be appropriate for the current study.

\subsection{Procedures}

Initially, we have conducted validity and reliability analysis to validate the survey questionnaire. To do this, we have used factor analysis, Cronbach's Alpha analysis, discriminant and convergent validity analysis respectively. After validity and reliability analysis, we have employed structural equations modeling to test the hypotheses of the study. Results were interpreted in the conclusion part of the study.

\section{Hypothesis testing and findings}

\subsection{Demographic descriptive}

Given in the Table 1, most of the participants were between 18 and 25 years old (50.8\%) and 26 and 35 years old (33.5\%). Secondly, there various types of participants who were patient (45.3\%), relative of patient (36.6\%) and friend of patient (18.1). Lastly, respondents were predominantly females $(64.4 \%)$ while men respondents were $35.6 \%$. Please see Table 1 for the further details. 


\section{EJMSS Eurasian Journal of Management \& Social Sciences}

Table 1: Demographic distribution

\begin{tabular}{llllll}
\hline Age & Proportion & Relation with hospital & Proportion & Gender & Proportion \\
\hline $18-25$ & 50.8 & Friend of patient & 18.1 & Female & 64.4 \\
\hline $26-35$ & 33.5 & Patient & 45.3 & Male & 35.6 \\
\hline $36-45$ & 8.9 & Relative of patient & 36.6 & & \\
\hline $46-55$ & 6.3 & & & \\
\hline $56+$ & 0.5 & & & \\
\hline
\end{tabular}

\subsection{Validity and reliability}

We have conducted confirmatory factor analysis for the initial validity and Cronbach's Alpha for the initial reliability of the questionnaire. For the confirmatory factor analysis, model fit values are important to check. There are two kinds of model fit values, comparative fit and absolute fit values. Comparative fit (CFI) was checked for the comparative fit and $\mathrm{x}^{2} / \mathrm{df}$, root mean squared error of estimation (RMSEA), good fit index (GFI) and adjusted good fit index (AGFI) were checked for the absolute fit values.

Table 2: CFA results

\begin{tabular}{|c|c|c|c|c|c|}
\hline Construct & Items & Mean & S.D. & Loading & Cronbach's Alpha \\
\hline \multirow[t]{4}{*}{ Functional Quality } & $\begin{array}{l}\text { Functional } \\
\text { Quality1 }\end{array}$ & 6.34 & 2.158 & 0.828 & 0.843 \\
\hline & $\begin{array}{l}\text { Functional } \\
\text { Quality2 }\end{array}$ & 6.39 & 2.070 & 0.809 & \\
\hline & $\begin{array}{l}\text { Functional } \\
\text { Quality3 }\end{array}$ & 6.83 & 2.092 & 0.761 & \\
\hline & $\begin{array}{l}\text { Functional } \\
\text { Quality4 }\end{array}$ & 6.48 & 2.033 & 0.815 & \\
\hline
\end{tabular}




\section{EJMSS Eurasian Journal of Management \& Social Sciences}

\begin{tabular}{|c|c|c|c|c|c|}
\hline & $\begin{array}{l}\text { Functional } \\
\text { Quality5 }\end{array}$ & 6.88 & 2.131 & 0.856 & \\
\hline & $\begin{array}{l}\text { Functional } \\
\text { Quality6 }\end{array}$ & 7.12 & 2.067 & 0.866 & \\
\hline & $\begin{array}{l}\text { Functional } \\
\text { Quality7 }\end{array}$ & 7.04 & 2.026 & 0.788 & \\
\hline & $\begin{array}{l}\text { Functional } \\
\text { Quality8 }\end{array}$ & 6.79 & 1.979 & 0.765 & \\
\hline \multirow[t]{5}{*}{ Technical Quality } & $\begin{array}{l}\text { Technical } \\
\text { Quality1 }\end{array}$ & 6.49 & 2.101 & 0.902 & \multirow[t]{5}{*}{0.827} \\
\hline & $\begin{array}{l}\text { Technical } \\
\text { Quality2 }\end{array}$ & 6.44 & 1.992 & 0.913 & \\
\hline & $\begin{array}{l}\text { Technical } \\
\text { Quality3 }\end{array}$ & 6.57 & 1.973 & 0.866 & \\
\hline & $\begin{array}{l}\text { Technical } \\
\text { Quality4 }\end{array}$ & 6.53 & 1.882 & 0.854 & \\
\hline & $\begin{array}{l}\text { Technical } \\
\text { Quality5 }\end{array}$ & 6.37 & 2.087 & 0.716 & \\
\hline \multirow[t]{5}{*}{ Trust } & Trust1 & 6.36 & 2.142 & 0.872 & \multirow[t]{5}{*}{0.834} \\
\hline & Trust2 & 6.37 & 2.052 & 0.892 & \\
\hline & Trust3 & 6.24 & 2.183 & 0.846 & \\
\hline & Trust4 & 6.23 & 2.099 & 0.829 & \\
\hline & Trust5 & 6.24 & 2.077 & 0.912 & \\
\hline \multirow[t]{2}{*}{ Loyalty } & Loyalty1 & 5.93 & 2.373 & 0.891 & \multirow[t]{2}{*}{0.845} \\
\hline & Loyalty 2 & 5.41 & 2.497 & 0.874 & \\
\hline
\end{tabular}




\section{EJMSS Eurasian Journal of Management \& Social Sciences}

\begin{tabular}{lllll}
\hline Loyalty3 & 5.81 & 2.406 & 0.921 \\
& Loyalty4 & 5.88 & 2.419 & 0.918 \\
\hline
\end{tabular}

Model fit values

$$
\begin{gathered}
\text { RMSEA }=0.072 \\
\text { CFI }=0.92 \\
\text { GFI }=0.88 \\
\text { AGFI }=0.85
\end{gathered}
$$

Given in the Table 2, chi-square value was 3.215 and is accepted due to below threshold value, which is five. Secondly, RMSEA value was 0.072 and is also accepted as it is below one. CFI value is expected to be above 0.9, GFI and AGFI is expected to be above 0.85 . Results of the analysis show adequate fit due to all values met the thresholds.

Based on the model fit values, factor loadings are expected to be above 0.7 for each item under the concerning latent variable. Given in the Table 2, the concerning requirement was met. Lastly, Crobnach's Alpha value was expected to be at least 0.7 to be accepted as

\begin{tabular}{|c|c|c|c|c|c|}
\hline & CR & AVE & TRUST & $\begin{array}{l}\text { Functional } \\
\text { Quality }\end{array}$ & $\begin{array}{l}\text { Technical LOYALTY } \\
\text { Quality }\end{array}$ \\
\hline TRUST & 0.940 & 0.758 & $0.871^{a}$ & & \\
\hline $\begin{array}{l}\text { Functional } \\
\text { Quality }\end{array}$ & 0.939 & 0.659 & $0.865^{b}$ & 0.872 & \\
\hline $\begin{array}{l}\text { Technical } \\
\text { Quality }\end{array}$ & 0.930 & 0.728 & 0.865 & 0.850 & 0.853 \\
\hline
\end{tabular}
reliable. It was observed that all those values were well above 0.7 therefore, initial reliability and validity was achieved.

Table 3: Discriminant and convergent validity 


\section{EJMSS}

\section{Eurasian Journal of Management \& Social Sciences}

\begin{tabular}{lllllcc}
\hline LOYALTY & 0.945 & 0.812 & 0.860 & 0.691 & 0.662 & 0.901 \\
*** a: square root of average variance extracted; b: correlation values &
\end{tabular}

After the initial validity and reliability, questionnaire cannot be validated unless convergent and discriminant validities are both achieved. Discriminant validity measures whether there is sufficient distance among the latent variables while convergent validity measures the sufficient correlation among each item under the concerning construct. However, discriminant validity is considered to be achieved if square root of average variance extracted is above the correlation of concerning latent variable with the other constructs. Secondly, convergent validity is achieved if composite reliability (at least must be 0.7 ) and average variance extracted (at least must be 0.5 ) are at sufficient values. Given in the Table 3 , square root of average variance extracted were all above the correlation values with other dimensions. Therefore, discriminant validity was achieved. Secondly, composite reliability and average variance extracted values all were above the aforementioned threshold values. Hence, convergent validity was achieved. In the next step, hypotheses were tested.

\subsection{Hypotheses testing}

Structural equations modeling was developed to test the hypothesized model. In this concept, we have divided service quality into two main parts mainly, technical quality and functional quality. Consequently, we have tested the impacts of those two constructs on the trust and loyalty. Secondly, we have tested the impact of trust on loyalty.

Table 4: Results of hypothesis

\begin{tabular}{|c|c|c|c|c|c|c|c|}
\hline $\begin{array}{l}\text { Dependent } \\
\text { Variable }\end{array}$ & & $\begin{array}{l}\text { Independent } \\
\text { Variable }\end{array}$ & Estimate & S.E. & $\mathrm{t}$ stat & $\begin{array}{l}\mathrm{p} \\
\text { value }\end{array}$ & Result \\
\hline Trust & $<---$ & $\begin{array}{l}\text { Functional } \\
\text { Quality }\end{array}$ & 0.463 & 0.153 & 3.020 & 0.003 & Accepted \\
\hline Trust & $<---$ & $\begin{array}{l}\text { Technical } \\
\text { Quality }\end{array}$ & 0.438 & 0.143 & 3.053 & 0.002 & Accepted \\
\hline Loyalty & $<---$ & $\begin{array}{l}\text { Functional } \\
\text { Quality }\end{array}$ & 0.178 & 0.192 & 0.926 & 0.355 & Rejected \\
\hline
\end{tabular}




\section{EJMSS Eurasian Journal of Management \& Social Sciences}

\begin{tabular}{lcllllll}
\hline Loyalty & $<---$ & $\begin{array}{l}\text { Technical } \\
\text { Quality }\end{array}$ & 0.099 & 0.181 & 0.757 & 0.306 & Rejected \\
& & & & & & \\
\hline Loyalty & $<---$ & Trust & 0.765 & 0.100 & 11.615 & $* * *$ & Accepted
\end{tabular}

Given in the Table 4 , there are results of analyses. It was revealed that functional service quality $(\beta=0.463, \mathrm{t}=3.020, \mathrm{p}<0.01)$ and technical service quality $(\beta=0.438, \mathrm{t}=3.053$, $\mathrm{p}<0.01$ ) at private hospitals had significant and positive direct impact on the trust of patients, relatives of patients, and friends of patients to the concerning private hospital. Therefore, H1, and $\mathrm{H} 2$ have been accepted.

Secondly, it was observed that neither functional service quality $(\beta=0.178, \mathrm{t}=0.926$, $\mathrm{p}>0.05)$ nor technical service quality $(\beta=0.099, \mathrm{t}=0.757, \mathrm{p}>0.05)$ at private hospitals had significant impact on the loyalty of patients, relatives of patients or friends of patients to the concerning private hospital. Therefore, H3 and H4 have been rejected.

Lastly, trust $(\beta=0.765, \mathrm{t}=11.615, \mathrm{p}<0.01)$ of patients, relatives of patients, and friends of patients had significant and positive impact on the loyalty to the concerning private hospital. Thus, H5 has been accepted. Further results can be observed on the Table 4 and Figure 2.

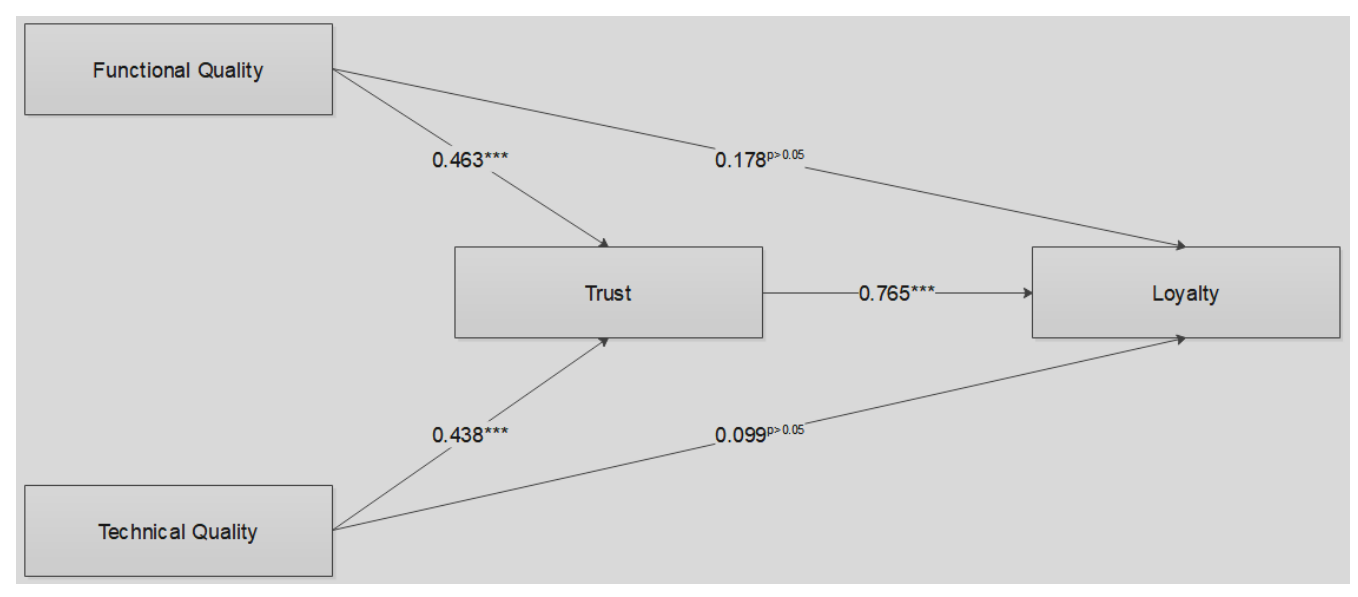

Figure 2: Model results 


\section{EJMSS}

\section{Eurasian Journal of Management \& Social Sciences}

\section{Conclusion}

The aim of the current study was to investigate the impact of technical service quality and functional service quality at private hospitals on the trust and loyalty of the patients, relatives of the patients and friends of the patients to that private hospital. To do this, we have collected data from various private hospitals in Sulaymaniyah and Erbil, which are the major and the most crowded cities of Kurdistan Region of Iraq.

Collected data was analyzed via structural equations modeling. The results revealed that functional and technical quality more or less had equal impact on the trust of patients to the services of that private hospital. Thus, we can suggest that if management of a private hospital makes empathy about, behaves responsive and be friendly with the patients and acquaintances of a patient (functional quality), it makes equal impact on the trust to that hospital as it does if doctors are very knowledgeable, operations are error free, diagnostics are punctual and to the point (technical quality). Therefore, we can't separate functional quality from the technical quality in hospitals.

The results reveal that trust had direct and significant impact on the loyalty of the patients to that private hospital. Besides, it was observed that functional and technical quality didn't have a significant impact on the loyalty. This result show that patients doesn't show loyalty to a private hospital unless they trust it. From this point of view, it was found that trust is a strong mediator between service quality and loyalty at private hospitals in Kurdistan region of Iraq.

There are some limitations of the current study. Initially, we have collected data from only private hospitals of Kurdistan Region of Iraq. Therefore, the study can't be generalized. Secondly, the findings are not conceptual or longitudinal but empirical therefore may show change based on the market, culture, geography...etc. Hence, the studies in the future can be conducted in various geographies and markets to see the similarities and differences. Secondly, studies in the future can include brand experience to test the impact of it on the trust and loyalty in this sector. 


\section{EJMSS}

\section{Eurasian Journal of Management \& Social Sciences}

\section{References}

Alrubaiee, L., \& Alkaa'ida, F. (2011). The mediating effect of patient satisfaction in the patients' perceptions of healthcare quality-patient trust relationship. International Journal of Marketing Studies, 3(1), 103.

Arab, M., Tabatabaei, S. G., Rashidian, A., Forushani, A. R., \& Zarei, E. (2012). The effect of service quality on patient loyalty: a study of private hospitals in Tehran, Iran. Iranian journal of public health, 41(9), 71.

Budur, T. (2018b). The impact of Al-Ghazali's virtues on organizational commitment and performance: A case Study at private education institutions in Kurdistan Region of Iraq. Icabep, Erbil-Iraq, 2, p21.

Budur, T. B. (2018a). Analytic Hierarchy Process to Evaluate Corporate Image, Trust, and Switching Cost of GSM Operators: A Case of Kurdistan Region of Iraq. International Journal of Social Sciences \& Educational Studies, 5(2), 241-250.

Budur, T., \& Demir, A. (2019a). Leadership effects on employee perception about CSR in Kurdistan Region of Iraq. International Journal of Social Sciences \& Educational Studies, 6(1). 142-154.

Budur, T., \& Demir, A. (2019b). Leadership perceptions based on gender, experience, and education. International Journal of Social Sciences \& Educational Studies, $6(1), 142-154$.

Budur, T., Faraj, K. M., \& Karim, L. A. (2019). The Benchmarking Operations Strategies via Hybrid Model: A Case study of Café-Restaurant Sector. Amazonia Investiga, 8(23), 842-854.

Budur, T., Rashid, C. A., \& Poturak, M. (2018). Students perceptions on university selection, decision making process: A case study in Kurdistan Region of Iraq. International Journal of Social Sciences \& Educational Studies, 5(1), 133-144.

Budur, T., \& Poturak, M. (2020). Transformational Leadership and its Impact on Customer Satisfaction. Measuring Mediating Effects of Organizational Citizenship Behaviors. Middle East Journal of Management.

Choudhuri, P. S. (2016). An Empirical Study on the Quality of Services Offered by the Private Life Insurers in Burdwan. In Handbook of Research on Promotional Strategies and Consumer Influence in the Service Sector (pp. 31-55). IGI Global.

Dachyar, M., \& Minar, I. P. (2018). Patients' Loyalty Improvement in Public Hospital. In MATEC Web of Conferences (Vol. 248, p. 03015). EDP Sciences.

Demir A, Shawkat S, Majeed BN, Budur T. 2019. Fuzzy AHP and VIKOR to select best location for bank investment: case study in Kurdistan Region of Iraq. In Effective Investments on Capital Markets, Tarczyn'sk W, Nermend K (eds). Springer: Cham; 485-510. 
Demir, A. (2019b). The Impact of Strategic Operations Management Decisions on Shoppers' wellbeing. Asian Academy of Management Journal, 24(1).

Demir, A. D. (2019a). A Benchmarking of service quality in telecommunication services: Case study in Kurdistan Region of Iraq. International Journal of Social Sciences \& Educational Studies, 5(3), 216-231.

Demir, A., \& Aydinli, C. (2016). Exploring the quality dimensions of mobile instant messaging applications and effects of them on customer satisfaction. International Journal of Computer Theory and Applications, 9(22), 1-15.

Demir, A., \& Budur, T. (2019). Roles of leadership styles in corporate social responsibility to non-governmental organizations (NGOs). International Journal of Social Sciences \& Educational Studies, 5(4), 174-183.

Demir, A., \& Guven, S. (2017). The influence of ISO certificate on quality evaluation of students: a case study at Ishik University. Advances in Social Sciences Research Journal, 4(3).

Demir, A., \& Mukhlis, M. (2017). An evaluation of gated communities as a product: An empirical study in Sulaimaniyah, Iraq. Theoretical and Empirical Researches in Urban Management, 12(3), 63-84.

Demir, A., Özmen, Ö., \& Rashid, A. (2014). An Estimation of Turkey's Export Loss to Iraq. Procedia-Social and Behavioral Sciences, 150, 1240-1247.

Ehsan, S. (2017). Interrelationships among quality enablers, service quality, patients' satisfaction and loyalty in hospitals, The TQM Journal.

Essay, U. (2015). The Five Dimensions of Service Quality Measured Marketing Essay.

Fatima, T., Malik, S. A., \& Shabbir, A. (2018). Hospital healthcare service quality, patient satisfaction and loyalty. International Journal of Quality \& Reliability Management.

Fisk, R. P., Grove, S. J., \& John, J. (2012). Services marketing self-portraits: Introspections, reflections, and glimpses from the experts. Marketing Classics Press.

Kesuma, I. A. W., Hadiwidjojo, D., Wiagustini, N. L. P., \& Rohman, F. (2013). Service quality influence on patient loyalty: Customer relationship management as mediation variable (study on private hospital industry in Denpasar).

International Journal of Business and Commerce, 2(12), 1-14.

Khan, N. U. S., \& Yildiz, Y. (2020). Impact of Intangible Characteristics of Universities on Student Satisfaction. Amazonia Investiga, 9(26), 105-116.

Lertwannawit, A., \& Gulid, N. (2011). International tourists service quality perception and behavioral loyalty toward medical tourism in bangkok metropolitan area. Journal of Applied Business Research (JABR), 27(6), 1-12. 
Lestariningsih, T., Hadiyati, E., \& Astuti, R. (2018). Study of service quality and patient satisfaction to trust and loyalty in public hospital, Indonesia. International Journal of Business Marketing and Management, 3(2), 1-12.

Martin, A. B., Lassman, D., Washington, B., Catlin, A., \& National Health Expenditure Accounts Team. (2012). Growth in US health spending remained slow in 2010; health share of gross domestic product was unchanged from 2009. Health Affairs, 31(1), 208-219.

Meesala, A., \& Paul, J. (2018). Service quality, consumer satisfaction and loyalty in hospitals: Thinking for the future. Journal of Retailing and Consumer Services, 40, 261-269.

Melisidou, S., \& Theocharis, N. (2007). Service Quality, Customer Satisfaction and Customer Retention in the hospitality industry: Keys to achieve tourism growth. In 2nd International Scientific Conference (eRA 2), "The Conference for the contribution of Information Technology to Science, Economy, Society and Education", TEI of Piraeus-University of Paisley, Aegina (pp. 22-23).

Mohammed, S. S., Suleyman, C., \& Taylan, B. (2020). Burnout Determinants and Consequences Among University Lecturers. Amazonia Investiga, 9(27), 13-24.

Moliner, M. A. (2009). Loyalty, perceived value and relationship quality in healthcare services. Journal of service management.

Moore, M., Anthony, C. R., Lim, Y. W., Jones, S. S., Overton, A., \& Yoong, J. K. (2014). The Future of Health Care in the Kurdistan Region-Iraq: Toward an Effective, High-Quality System with an Emphasis on Primary Care. Rand health quarterly, 4(2).

Özmen, Ö., Demir, A., \& Celepli, M. (2013). An Analysis of Iraq's Pre-import Inspection, Testing \& Certification Program: A’WOT Analysis. ProcediaSocial and Behavioral Sciences, 99, 85-93.

Rahman, M. R., \& Kutubi, S. S. (2013). Assessment of service quality dimensions in healthcare industry A study on patient's satisfaction with Bangladeshi private Hospitals. International Journal of Business and Management Invention, 2(4), 59-67.

Rehaman, B., \& Husnain, M. (2018). The impact of service quality dimensions on patient satisfaction in the private healthcare industry in Pakistan. J Hosp Med Manage [Internet]. Retrieved from: https://investingroup.org/review/245/on-track-forexpansion-health-kurdistan/

Shabbir, A., \& Malik, S. A. (2016). Measuring patients' healthcare service quality perceptions, satisfaction, and loyalty in public and private sector hospitals in Pakistan. International Journal of Quality \& Reliability Management, 33(5), 538-557. 


\section{EJMSS Eurasian Journal of Management \& Social Sciences}

Suki, N. M. (2011). Assessing patient satisfaction, trust, commitment, loyalty and doctors' reputation towards doctor services. Pakistan Journal of Medical Science, 27(5), 1207-1210.

Sumaedi, S., Bakti, I. G. M. Y., Rakhmawati, T., Astrini, N. J., Yarmen, M., \& Widianti, T. (2015). Patient loyalty model. Leadership in Health Services.

Top, C., Abdullah, B. M. S., \& Faraj, A. H. M. (2020). Transformational Leadership Impact on Employees Performance.

Torlak, N. G., Demir, A., \& Budur, T. (2019). Impact of operations management strategies on customer satisfaction and behavioral intentions at caférestaurants. International Journal of Productivity and Performance Management.

Wu, C. C. (2011). The impact of hospital brand image on service quality, patient satisfaction and loyalty. African Journal of Business Management, 5(12), 4873.

Yildiz, Y., \& Amin, H. H. H. (2020). Impact of Organizational Citizenship Behavior on Customer Satisfaction.

Yildiz, Y., \& Budur, T. (2019). Introducing Environmental Awareness to College Students with Curricular and Extracurricular Activities. International journal of Academic Research in business and Social Sciences, 9(3)667-675.

Zaim, H., Demir, A., \& Budur, T. (2020). Ethical Leadership, Effectiveness and Team Performance: An Islamic Perspective. Middle East Journal of Management.

Zeithaml, V. A., Parasuraman, A., Berry, L. L., \& Berry, L. L. (1990). Delivering quality service: Balancing customer perceptions and expectations. Simon and Schuster. 